\title{
Kemampuan Berpikir Kreatif Siswa dalam Mem-posing Masalah menggunakan Pendekatan Pendidikan Matematika Realistik Indonesia
}

\author{
Elisa Anggraini ${ }^{1}$, Zulkardi $^{*}$ \\ ${ }^{1,2}$ Program Studi Pendidikan Matematika, Universitas Sriwijaya \\ *zulkardi@unsri.ac.id
}

\begin{abstract}
Abstrak
Tujuan penelitian ini adalah untuk memeroleh gambaran bagaimana kemampuan berpikir kreatif siswa dalam mengajukan masalah dengan menggunakan pendekatan Pendidikan Matematika Realistik Indonesia (PMRI) dengan materi pola bilangan. Penelitian ini menggunakan penelitian deskriptif dengan siswa kelas VIII di SMP Negeri 15 Palembang sebagai subjek penelitian. Proses pembelajaran yang dilakukan di kelas sesuai dengan pendekatan PMRI. Teknik pengumpulan data yang digunakan yaitu tes, observasi, dan wawancara. Dilakukannya observasi yaitu untuk melihat indikator yang muncul saat proses pembelajaran dilaksanakan. Tes dilakukan untuk menentukan kemampuan berpikir kreatif siswa ketika mengerjakan dan mengajukan masalah. Sedangkan dilakukannya wawancara digunakan untuk mengkonfirmasi jawaban hasil tes siswa. Hasil penelitian ini kemudian dibedakan ke dalam 5 tingkatan dengan karakteristik yang berbeda pada tiap tingkatan, yaitu level 0 hingga level 4. Pada penelitian ini terdapat 4 siswa yang berkemampuan sangat kreatif, 18 siswa yang berkemampuan kreatif, 2 siswa yang memiliki berkemampuan kurang kreatif, dan 2 siswa yang berkemampuan tidak kreatif. Perbedaan tiap tingkatan tersebut didasarkan pada kelancaran, fleksibilitas, dan kebaruan dalam mengajukan dan menyelesaikan masalah.
\end{abstract}

Kata kunci: berpikir kreatif, pengajuan masalah, PMRI

\begin{abstract}
This research aims to obtain a picture of how students' creative thinking abilities in proposing problems using Pendidikan Matematika Realistik Indonesia (PMRI) approach on the material of number patterns. This research uses descriptive research with the research subject is students of class VIII at SMP Negeri 15 Palembang. The learning process in the class was carried out by the PMRI approach. Data collection techniques used in this study were tests, observations, and interviews. Observations were made to see the indicators that emerge when the learning process was carried out. Tests were conducted to determine students' creative thinking abilities when working on and proposing problems. At the same time, interviews were used to confirm answers to student test results. The results are divided into five levels, namely level 0 to level 4, with different characteristics at each level. In this research, there are four students with very creative abilities, 18 students with creative abilities, two students with less creative abilities, and two students with non-creative abilities. The difference in each level is based on fluency, flexibility, and novelty in posing problems.
\end{abstract}

Keywords: creative thinking, PMRI, problem posing

Received: January 20, 2020 | Accepted: July 3, 2020 | Published Online: July 30, 2020 


\section{Pendahuluan}

Pola bilangan merupakan salah satu dari 8 tujuan pembelajaran matematika SMP, dimana pola bilangan dapat digunakan sebagai salah satu cara untuk menduga dari sebuah penyelesaian masalah (Juliant \& Kurnia, 2016). Pola bilangan juga termasuk salah satu materi yang ada dalam USBN dan Ujian Nasional baik SMP maupun SMA. Selain itu, pola bilangan juga sering ditemui pada soal-soal masuk perguruan tinggi maupun tes lainnya seperti PISA, TIMMS ataupun tes seleksi PNS. Meskipun demikian, masih banyak siswa yang mengalami kesulitan dalam menjawab soal yang terkait materi pola bilangan.

Siswa masih banyak mengalami kesalahan dalam menjawab soal yang berkaitan dengan pola bilangan. Dalam penelitian Susanti dan Setianingsih (2019) menunjukkan bahwa siswa tidak dapat menemukan informasi utama pada soal tentang pola bilangan karena siswa kurang teliti dan tidak memahami soal. Hal ini juga serupa pada observasi yang dilakukan pada saat pembelajaran, yaitu materi yang sulit dipahami siswa adalah pola bilangan, karena siswa langsung berhubungan dengan konsep yang abstrak dan masih pada hafalan, sehingga siswa tidak dapat menemukan konsep pola bilangan itu sendiri (Disnawati \&Nahak, 2019). Selain itu juga, hal yang menyebabkan rendahnya tingkat kemampuan berpikir kreatif yaitu siswa salah mengartikan soal (Widyastuti \& Putri, 2018). Untuk itu siswa juga perlu untuk mengajukan sendiri suatu masalah agar siswa dapat mengetahui maksud dari soal. Dalam mengajukan masalah, siswa diharapkan menjadi lebih kreatif, sehingga diperlukannya kemampuan berpikir kreatif siswa dalam mengajukan masalah.

Berpikir kreatif merupakan salah satu kemampuan yang ada pada kompetensi kecakapan abad 21, yaitu peserta didik baik secara mandiri maupun kelompok diharapkan dapat menghasilkan, mengembangkan, dan mengimplementasikan ide secara kreatif (Kemdikbud, 2018). Namun, kemampuan berpikir kreatif di Indonesia masih tergolong rendah. Kreativitas Indonesia berada di peringkat 115 dari 139 negara berdasarkan data pada Global Creativity Index (Florida, dkk., 2015). Selain itu juga terdapat penelitian yang hasilnya mengatakan bahwa hasil dari kemampuan berpikir kreatif siswa sebanyak 77,5\% masih tergolong rendah (Safaria \& Sangila, 2018). Rendahnya kemampuan berpikir kreatif siswa mengakibatkan siswa tidak bisa menyelesaikan permasalahan, terutama yang berkaitan pada kehidupan sehari-hari. Oleh karena itu, kemampuan berpikir kreatif perlu dimiliki oleh siswa.

Sesuai dengan kenyataan tersebut, diperlukan pembelajaran yang dapat meningkatkan kemampuan berpikir kreatif siswa. Salah satu pembelajaran yang dapat digunakan yaitu dengan menggunakan pendekatan Pendekatan Matematika Realistik Indonesia (PMRI). PMRI 
merupakan suatu pendekatan untuk meningkatkan mutu pendidikan matematika di Indonesia yang idenya berasal dari Realistic Mathematics Education (Zulkardi, 2002). PMRI berpusat pada siswa untuk membentuk pengetahuannya sendiri melalui keaktifannya di kelas dan lebih mementingkan aktivitas siswa dalam proses pembelajaran, sehingga mampu membangun pengetahuannya sendiri (Idris \& Silalahi, 2016). Selain itu, dengan PMRI pembelajaran akan lebih mudah diajarkan karena pembelajaran yang cocok untuk menggunakan konteks ataupun situasi yang diberikan salah satunya yaitu PMRI (Fauziah, Zulkardi, \& Putri, 2016; Situmorang \& Zulkardi, 2019). Pada pembelajaran mengunakan PMRI, terdapat pengaruh pada kemampuan berpikir kreatif siswa (Lestari, Testiana, \& Agustina, 2018). Penelitian lain juga menyatakan bahwa lebih dari 30\% siswa memiliki kemampuan berpikir kreatif dengan menggunakan PMRI (Mulinda, Zubainur, \& Hidayat, 2018).

Penelitian-penelitian sudah banyak megkaji mengenai keterkaitan antara penggunaan pendekatan PMRI dalam meningkatkan kemampuan berpikir kreatif, namun belum lebih spesifik kepada penggunaan problem posing. Berkaitan dengan itu, peneliti tertarik melakukan penelitian untuk memperoleh gambaran kemampuan berpikir kreatif siswa dalam mengajukan masalah menggunakan PMRI pada materi pola bilangan yang dilakukan di kelas VIII.

\section{Metode}

Metode penelitian yang dilakukan pada penelitian ini adalah penelitian deskriptif. Penelitian deskriptif adalah penelitian yang digunakan untuk mengetahui fenomena/perubahan yang ada terhadap aktivitas dari kejadian saat ini atau saat lampau (Asep, 2014). Peneliti menggunakan jenis penelitian ini untuk memperoleh gambaran bagaimana kemampuan berpikir kreatif siswa dalam mengajukan masalah menggunakan pendekatan PMRI. Penelitian ini dilaksanakan di SMP Negeri 15 Palembang pada semester ganjil tahun pelajaran 2019/2020. Subjek penelitian ini adalah siswa kelas VIII SMP Negeri 15 Palembang yang terdiri dari 26 siswa. Adapun instrumen penelitian yang digunakan yaitu Rencana Pelaksanaan Pembelajaran (RPP) dan Lembar Kerja Peserta Didik (LKPD) yang dibuat berdasarkan karakteristik PMRI serta lembar observasi saat pembelajaran berlangsung, serta soal tes dan pedoman wawancara. Teknik pengumpulan data yang digunakan peneliti yaitu observasi, tes, dan wawancara. Untuk mengetahui kemunculan indikator kemampuan berpikir kreatif pada saat pembelajaran berlangsung, peneliti melakukan observasi. Tes dilakukan untuk menentukan tingkat kemampuan berpikir kreatif siswa ketika mengerjakan dan mengajukan masalah. Sedangkan untuk mengkonfirmasi jawaban hasil tes siswa, peneliti 
melakukan wawancara. Adapun teknik analisis data yang dilakukan yaitu menganalisis data hasil tes, observasi dan wawancara.

Dalam menganalisis data hasil tes, peneliti menggunakan rubrik penskoran berdasarkan indikator kemampuan berpikir kreatif sebagai berikut.

Tabel 1. Pedoman Penskoran Kemampuan Berpikir Kreatif

\begin{tabular}{|c|c|c|}
\hline $\begin{array}{l}\text { Aspek yang } \\
\text { diukur }\end{array}$ & Respon Siswa & Skor \\
\hline \multirow[t]{5}{*}{ Fluency } & $\begin{array}{l}\text { Tidak memberikan pertanyaan atau memberikan satu } \\
\text { pertanyaan namun pertanyaan sulit dipahami }\end{array}$ & 0 \\
\hline & $\begin{array}{l}\text { Memberikan satu pertanyaan, namun jawaban salah atau } \\
\text { pertanyaan tidak relevan }\end{array}$ & 1 \\
\hline & Memberikan lebih dari satu pertanyaan, namun jawaban salah & 2 \\
\hline & Memberikan satu pertanyaan dan jawaban benar & 3 \\
\hline & Memberikan lebih dari satu pertanyaan dan jawaban benar & 4 \\
\hline \multirow[t]{5}{*}{ Flexibility } & Tidak merespon soal atau menjawab pertanyaan namun salah & 0 \\
\hline & $\begin{array}{l}\text { Hanya menyelesaikan } 1 \text { soal dengan benar tanpa membuat } \\
\text { pernyataan/ kondisi baru dari gambar yang diberikan }\end{array}$ & 1 \\
\hline & $\begin{array}{l}\text { Menyelesaikan } 2 \text { soal dengan benar dan tidak membuat } \\
\text { pernyataan/ kondisi baru dari gambar yang diberikan }\end{array}$ & 2 \\
\hline & $\begin{array}{l}\text { Menyelesaikan soal dengan benar dan membuat pernyataan/ } \\
\text { kondisi namun tidak relevan/ tidak sesuai }\end{array}$ & 3 \\
\hline & $\begin{array}{l}\text { Menyelesaikan soal dengan benar dan membuat pernyataan/ } \\
\text { kondisi yang sesuai/ relevan }\end{array}$ & 4 \\
\hline \multirow[t]{5}{*}{ Novelty } & Tidak merespon soal atau tidak membuat pertanyaan & 0 \\
\hline & $\begin{array}{l}\text { Membuat pertanyaan dengan modifikasi (konteks atau konsep } \\
\text { baru) namun tidak dapat dipahami }\end{array}$ & 1 \\
\hline & $\begin{array}{l}\text { Membuat pertanyaan dengan modifikasi (konteks atau konsep } \\
\text { baru) namun kurang informasi sehingga tidak dapat } \\
\text { diselesaikan }\end{array}$ & 2 \\
\hline & $\begin{array}{l}\text { Membuat pertanyaan dengan modifikasi (konteks atau konsep } \\
\text { baru) namun jawaban salah }\end{array}$ & 3 \\
\hline & $\begin{array}{l}\text { Membuat pertanyaan dengan modifikasi (konteks atau konsep } \\
\text { baru) dan jawaban benar }\end{array}$ & 4 \\
\hline
\end{tabular}

Setelah memeriksa hasil tes siswa, kemudian peneliti menentukan skor siswa berdasarkan kemampuan berpikir kreatif siswa. Adapun rumus menentukan skornya sebagai berikut :

$$
T=\frac{J S}{S M} \times 100
$$

Keterangan :

$\mathrm{T} \quad=$ Nilai Tes Siswa

JS = Jumlah skor siswa

$\mathrm{SM}=$ Jumlah skor maksimum 
Setelah menentukan skor tes siswa, kemudian peneliti juga membuat rekap kemunculan indikator pada jaawaban hasil tes siswa. Selanjutnya diklasifikasi berdasarkan tingkat berpikir kreatif siswa (Silver, 1997) seperti pada tabel 2.

Tabel 2. Tingkat Kemampuan Berpikir Kreatif Siswa

\begin{tabular}{cl}
\hline Tingkat & Karakteristik Tingkat Berpikir Kreatif Siswa \\
\hline $\begin{array}{c}\text { Tingkat } 4 \\
\text { (sangat kreatif) }\end{array}$ & $\begin{array}{l}\text { Soal yang diajukan siswa memenuhi aspek fluency, } \\
\text { flexibility, dan novelty }\end{array}$ \\
\hline $\begin{array}{c}\text { Tingkat } 3 \\
\text { (kreatif) }\end{array}$ & $\begin{array}{l}\text { Soal yang diajukan siswa hanya memenuhi aspek fluency } \\
\text { dan novelty, atau flexibility dan novelty saja }\end{array}$ \\
\hline $\begin{array}{c}\text { Tingkat } 2 \\
\text { (cukup kreatif) }\end{array}$ & $\begin{array}{l}\text { Soal yang diajukan siswa memenuhi aspek fluency dan } \\
\text { flexibility }\end{array}$ \\
\hline $\begin{array}{c}\text { Tingkat } 1 \\
\text { (kurang kreatif) }\end{array}$ & Soal yang diajukan siswa hanya memenuhi aspek fluency \\
\hline $\begin{array}{c}\text { Tingkat } 0 \\
\text { (tidak kreatif) }\end{array}$ & Soal yang diajukan siswa tidak memenuhi ketiga aspek \\
\hline
\end{tabular}

Pada tingkat kemampuan berpikir kreatif tersebut, jika siswa hanya memenuhi flexibility saja, tidak masuk kedalam kelima tingkatan tersebut, karena flexibility biasanya disertai aspek lainnya, seperti siswa dalam mengajukan soal, apakah ia mengajukan soal dengan fleksibel dan lancar ataukah ia fleksibel dalam membuat soal yang baru. Pada aspek novelty, aspek ini merupakan aspek tertinggi dari kedua aspek lainnya, karena pada aspek ini siswa diminta untuk mengajukan soal yang baru atau berbeda dari soal sebelumnya. Oleh karena itu, pada aspek ini, novelty biasanya akan disertai dengan aspek lain dibawahnya, seperti siswa dapat mengajukan banyak soal yang baru dari konteks sebelumnya, ataupun siswa dapat mengajukan soal dengan luwes.

Hasil tes yang telah dilakuan dianalisis berdasarkan observasi di lapangan dan wawancara yang telah dilakukan peneltisi sebagai konfirmasi siswa dalam menjawab soal tes. Wawancara dilakukan pada 3 orang siswa yang diklasifikasikan berdasarkan soal yang mereka jawab.

Tabel 3. Tabel Klasifikasi Siswa

\begin{tabular}{cc}
\hline Nomor Soal & Kode Siswa \\
\hline Nomor 1 & S1 \\
\cline { 2 - 2 } & S2 \\
\hline Nomor 2 & S1 \\
\cline { 2 - 2 } & $\mathrm{S} 2$ \\
\hline Nomor 3 & S3 \\
\hline & S1 \\
\hline
\end{tabular}




\section{Hasil Penelitian}

Dalam penelitian ini, diperoleh hasil analisis kemampuan berpikir kreatif siswa berdasarkan kemunculan 172 indikator dan kategori yang dikemukakan oleh Silver (1997). Berikut adalah kemunculan indikator-indikator kemampuan berpikir kreatif siswa dapat dilihat pada tabel 4 .

Tabel 4. Frekuensi Kemunculan Indikator Kemampuan Berpikir Kreatif Siswa pada Soal Tes

\begin{tabular}{clccc}
\hline \multicolumn{2}{c}{$\begin{array}{c}\text { Jumlah Siswa yang } \\
\text { Memenuhi }\end{array}$} & $\mathbf{1}$ & $\mathbf{2}$ & $\mathbf{3}$ \\
\cline { 2 - 5 } Indikator & Fluency & 24 & - & 26 \\
\cline { 2 - 5 } & Flexibility & - & 21 & - \\
\cline { 2 - 5 } & Novelty & - & - & 5 \\
\hline
\end{tabular}

Setelah membuat rekapan frekuensi kemunculan indikator kemampuan berpikir kreatif siswa, kemudian peneliti mengklasifikasikannya berdasarkan kategori kemampuan berpikir kreatif siswa seperti pada tabel 5 berikut.

Tabel 5. Distribusi Frekuensi Kemampuan Berpikir Kreatif Siswa

\begin{tabular}{lcc}
\hline \multicolumn{1}{c}{ Indikator yang terpenuhi } & Kategori & Frekuensi \\
\hline Fluency, Flexibility, dan Novelty & Sangat Kreatif & 4 \\
\hline $\begin{array}{l}\text { Fluency dan Novelty atau Flexibility } \\
\text { dan } \text { novelty }\end{array}$ & Kreatif & 18 \\
\hline Fluency dan Flexibility & Cukup Kreatif & 0 \\
\hline Fluency & Kurang Kreatif & 2 \\
\hline Tidak Ada & Tidak Kreatif & 2 \\
\hline \multicolumn{1}{c}{ Jumlah } & & 26 \\
\hline
\end{tabular}

Berdasarkan tabel 5 terlihat bahwa hasil tes kemampuan berpikir kreatif siswa mencakup 4 kategori. Siswa yang berkemampuan sangat kreatif memenuhi keempat aspek tersebut hanya 4 siswa. Sedangkan siswa yang berkemampuan kreatif ada 18 siswa. Siswa dikategorikan kreatif karena memenuhi 2 dari 3 aspek, dimana salah satunya yaitu aspek yang paling sulit dalam berpikir kreatif, yaitu novelty. Tidak terdapat siswa di kategori cukup kreatif yang memenuhi aspek fluency dan flexibility. Terdapat 2 siswa pada kategori kurang kreatif. Siswa yang berada pada kategori kurang kreatif hanya memenuhi aspek fluency, dimana aspek ini merupakan aspek paling dasar dari kedua aspek lainnya. Terdapat 2 siswa yang berada pada kategori tidak kreatif, kedua siswa tersebut tidak memenuhi ketiga aspek tersebut.

Pada ketiga soal tersebut terlihat bahwa tidak ada siswa yang hanya memenuhi aspek flexibility saja, karena aspek tersebut juga muncul bersamaan dengan aspek fluency atau novelty. Begitupun juga pada aspek novelty, aspek ini juga muncul bersamaan dengan aspek fluenxy ataupun flexibility. 
Berikut analisis jawaban siswa berdasarkan nomor soal yang didukung dengan observasi dan wawancara dari subjek penelitian.

\section{Soal Nomor 1}

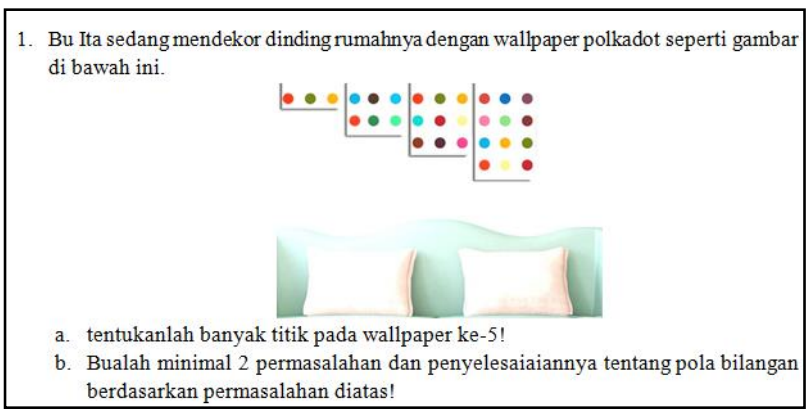

Gambar 1. Soal tes Nomor 1

Pada soal nomor 1, terdapat beberapa jenis jawaban siswa, terdapat siswa yang membuat pertanyaan dengan menanyakan banyak titik pada susunan tertentu dan juga terdapat siswa yang menanyakan bentuk umum dari pola yang diberikan. Pada pertanyaan yang menanyakan banyak titik pada susunan tertentu, siswa menyelesaikannya dengan cara melanjutkan konfigurasi objek yang diberikan, dan juga terdapat siswa yang menjawab langsung dengan bentuk umum (generalisasi) dari pola tersebut.

a. Siswa Pertama (S1)

S1 merupakan salah satu siswa yang menjawab dengan menggunakan bentuk umum pola bilangan tersebut. Pada saat pembelajaran berlangsung, S1 terlihat aktif bersama kelompoknya, baik saat pertemuan 1 maupun pertemuan II.

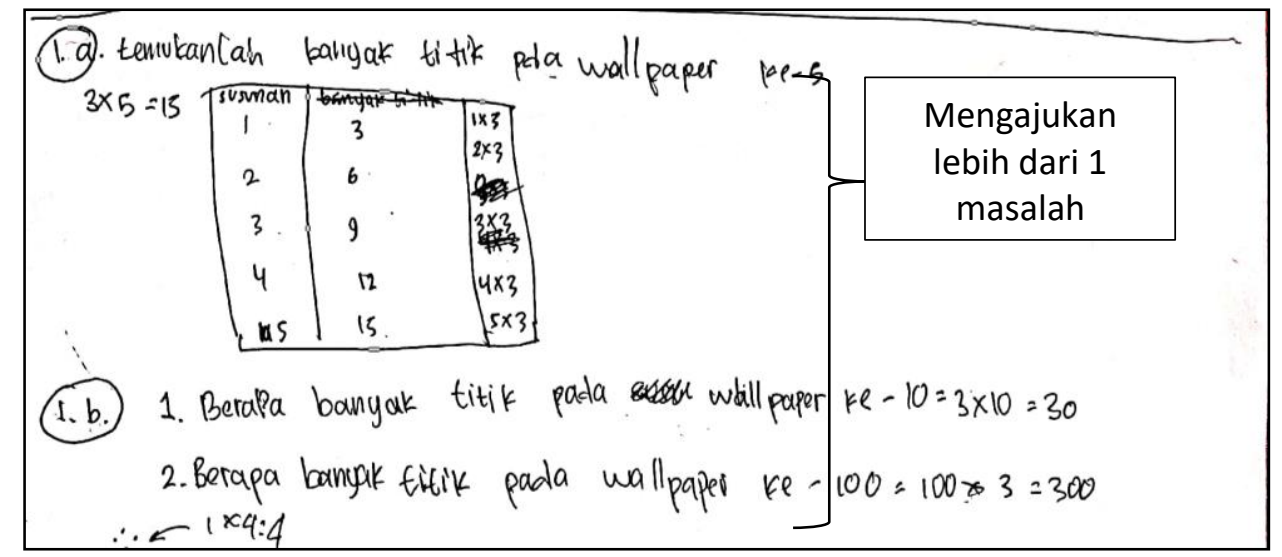

Gambar 2. Hasil Pengerjaan No. 1 oleh S1

S1 telah memunculkan indikator berpikir kreatif fluency secara maksimal dengan skor 4. Berdasarkan wawancara dengan S1 sudah mengetahui bentuk umum dari pola bilangan tersebut, sehingga ia dapat mengajukan pertanyaan susunan ke-10 ataupun ke-100, maupun susunan lainnya. Siswa S1 memilih susunan ke-10 dan ke-100 dikarenakan susunan itu yang 
mudah untuk dikalikan secara langsung. Hal ini didukung dengan wawancara peneliti dengan siswa S1 sebagai berikut.

Peneliti : untuk yang soal b, buatlah minimal 2 permasalahan dan penyelesaiannya tentang pola bilangan. Nah, di sini ngapo adek nak pola bilangan yang ke10 samo ke-100?

Siswa : kerena 10 dan 100 itu mudah dikalikan dan mudah dihitung.

Pada wawancara tersebut, siswa telah lancar untuk menemukan susunan ke-n berdasarkan bentuk umum yang telah ia temukan sendiri.

b. Siswa Kedua (S2)

S2 merupakan salah satu siswa yang telah mampu mengajukan lebih dari 1 pertanyaan dengan cara penyelesaiannya yaitu dengan menggambarkan lanjutan dari konfigurasi objek yang diberikan. Pada saat pembelajaran, S2 memang masih kurang memahami tentang bentuk umumnya, hal ini terlihat pada proses pembelajaran berlangsung, S2 terihat bingung saat ditanya tentang bentuk umum dari konfigurasi objek tersebut.

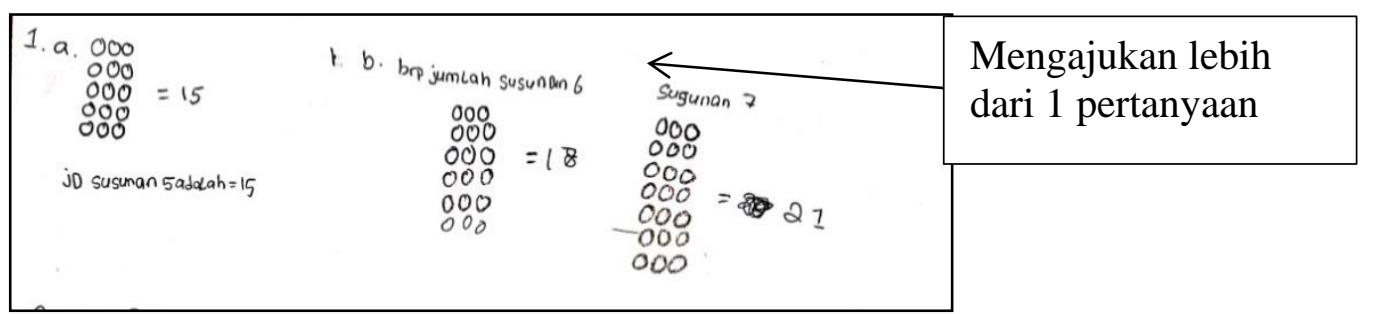

Gambar 3. Hasil Pengerjaan No. 1 oleh S2

Dari hasil jawaban di atas, siswa S2 telah mampu mengajukan lebih dari satu penyelesaian, sehingga S2 mendapatkan skor maksimal pada indikator kemampuan berpikir kreatif fluency yaitu dengan skor 4. Hal ini didukung dengan wawancara peneliti dengan siswa S2 sebagai berikut.

Peneliti : di soal No 1, untuk jawaban yang a adek dapet 15. Itu darimana?

Siswa : ditambah tiga, polanya ditambah tiga.

Peneliti : kalau maksud dari gambar ini adek apain sih?

Siswa : ditambahke hasilnyo 15.

Peneliti : adek tambain titik-titiknya ya.

Siswa : iya

Peneliti : kalau yang b, berapa jumlah susunan yang ke-6. Itu kayakmana caranya, sama aja?

Siswa : iya bu

Peneliti : kenapa adek mau 6 sama 7 ?

Siswa : karena mudah dihitung

Berdasarkan wawancara yang dilakukan, susunan pola yang diajukan juga masih pada pola yang dapat dihitung/ digambarkan, hal ini dikarenakan siswa tidak menggunakan bentuk umum dari pola yang diberikan. Berdasarkan wawancara yang dilakukan peneliti dengan 
siswa, S2 mengajukan masalah untuk pola ke-6 dan ke-7 dikarenakan mudah untuk menghitungnya/ mudah digambarkan.

\section{Soal Nomor 2}

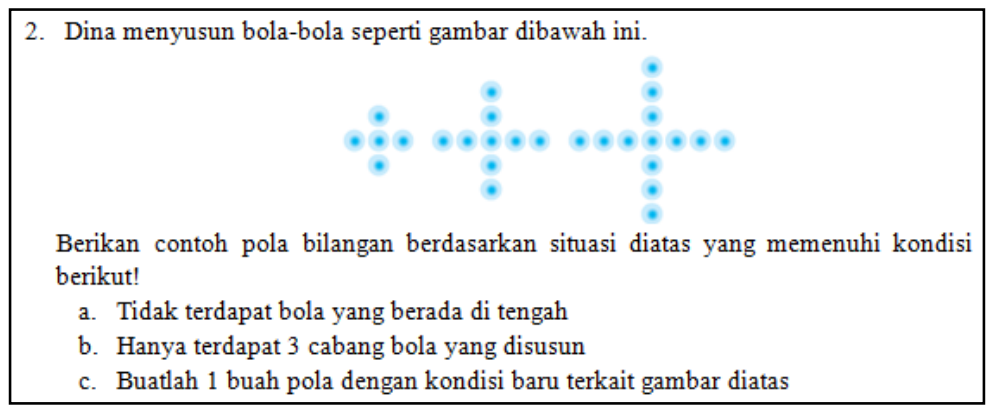

Gambar 4. Soal Tes nomor 2

Pada soal nomor 2, siswa diminta menuliskan pola yang diminta serta membuat suatu kondisi baru berkaitan dengan materi pola bilangan. Pada soal nomor $2 \mathrm{~b}$. Terdapat beberapa jenis jawaban siswa. Yaitu siswa membuat 3 cabang bola yang disusun dengan adanya bola yang berada ditengah dan tanpa bola yang berada ditengah sebagai pusat.

\section{a. Siswa Pertama (S1)}

$\mathrm{S} 1$ merupakan siswa yang menjawab soal nomor $2 \mathrm{a}$ dengan benar dan soal nomor $2 \mathrm{~b}$ dengan tanpa adanya bola ditengah. Serta pada soal nomor 2c S1 juga membuat kondisi baru dengan kondisi terdapat 2 cabang pola.

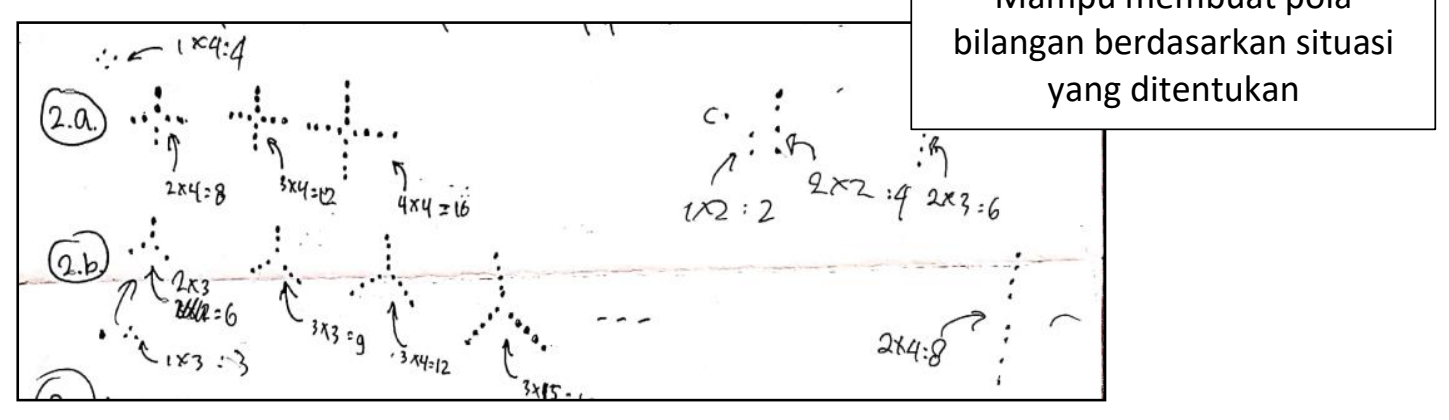

Gambar 5. Hasil Pengerjaan No. 2 oleh S1

Dari hasil jawaban tersebut, S1 sudah mampu membuat pola tertentu dengan menyertakan bentuk umum, meskipun tidak diminta untuk menuliskan bentuk umum. Sehingga S1 telah memunculkan indikator kemampuan berpikir kreatif bidang flexibility dengan memperoleh skor maksimal, yaitu 4. Hal ini didukung dengan wawancara peneliti dengan siswa S1 sebagai berikut.

Peneliti : untuk nomor $2 a$, adek bisa tau dari mana hasil perkaliannya?

Siswa : kan ini 4 cabang, disuruh yang tengahnya dihilangin, jadi inikan 4 cabang, dalam satu cabang ada 2 titik, jadi 4 kali 2 sama dengan 8.

Peneliti : untuk soal yang b nya juga? 
Siswa : (mengangguk)

Peneliti : kalau untuk yang 2c, kan kita disuruh buat kondisi baru. ini dapet dari mana kondisi barunya?

Siswa : (berpikir sejenak)

Peneliti : (menunjuk LKPD), kenapa adek mau 2 cabang?

Siswa : biar mudah dihitung.

Berdasarkan wawancara yang telah dilakukan, S1 dapan menjelaskan bagaimana ia bisa menemukan bentuk umum dari pola yang diberikan.

b. Siswa Kedua (S2)

S2 merupakan salah satu siswa yang menyelesaikan soal nomor $2 \mathrm{~b}$ dengan menggunakan bola ditengah sebagai pusat. Pada saat pembelajaran, S2 sering terlihat bingung, sehingga sering bertanya kepada peneliti. Berikut lembar jawaban S2 pada soal nomor 2

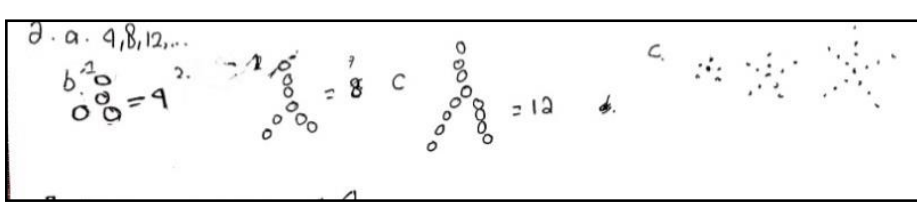

Mengajukan dan menjawab suatu kondisi dari pola bilangan, namun masih ada kekeliruan

Gambar 6. Hasil Pengerjaan No. 2 oleh S2

Dari hasil jawaban di atas, S2 telah mampu membuat pola sesuai kondisi yang diberikan, namun masih terdapat kekeliruan dalam menggambarkan ulang pola yang diminta. Sehingga kemunculan indikator kemampuan berpikir kreatif bidan flexibility masih belum maksimal. Oleh karena itu peneliti memberikan skor 3 kepada S2. Selain itu, S2 juga masih kelihatan bingung terhadap jawaban yang telah ia buat, hal ini didukung dengan wawancara peneliti dengan siswa $\mathrm{S} 2$.

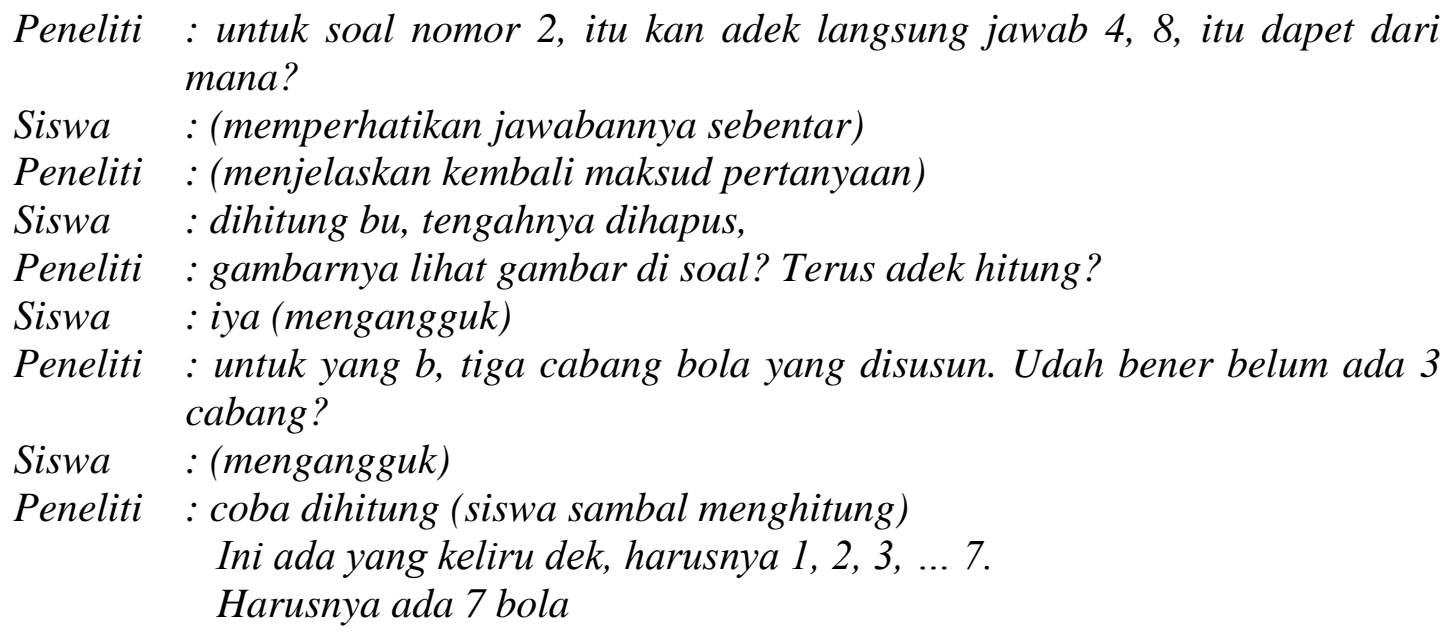

Selain itu pada wawancara berlangsung, S2 juga mengalami kebingungan saat ditanya, namun setelah dijelaskan kembali, S2 mengerti dari jawaban yang ia buat. Ia membuat pola baru dengan kondisi 5 cabang. Hal ini dikarenakan menurut S2 lebih mudah untuk dibuat. 


\section{c. Siswa Ketiga (S3)}

Dalam menjawab soal nomor 2, S3 masih belum bisa dalam menjawab soal tersebut. Hal ini terlihat pada jawaban S3 pada saat tes dilakukan. Pada proses pembelajaran juga S3 kurang aktif dalam diskusi kelompok. Berikut lembar jawaban S3 pada soal nomor 2.

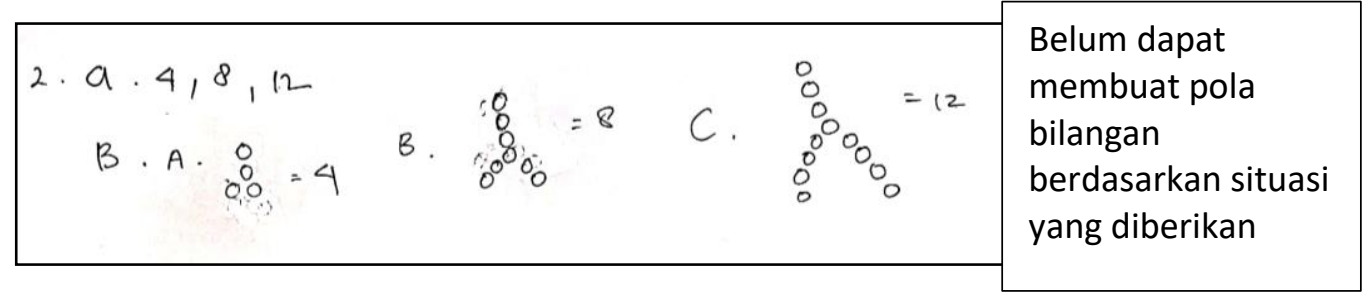

Gambar 7. Hasil Pengerjaan No. 2 oleh S3

Berdasarkan cuplikan gambar di atas, terlihat bahwa siswa sudah hampir terarah dengan yang dimaksud oleh soal. Seperti pada soal nomor 2, siswa membuat 3 cabang namun tidak sesuai dengan pola yang diminta, ehingga peneliti memberikan skor 0. Selain itu, pada saat pembelajaran maupun wawancara, SR terlihat bingung dalam menjawab pertanyaan yang diberikan oleh guru.

Peneliti : untuk yang b, terdapat 3 cabang bola yang disusun. Sebelumnya ibu tanya dulu, itu ada 3 cabang ga? (siswa mengangguk) Tapi disni kayaknya ada yang keliru. Coba perhatikan.

Siswa : (diajarkan kembali kekeliruannya)

Peneliti : jadi, mungkin tadi ada yang lupa.

\section{Soal Nomor 3}

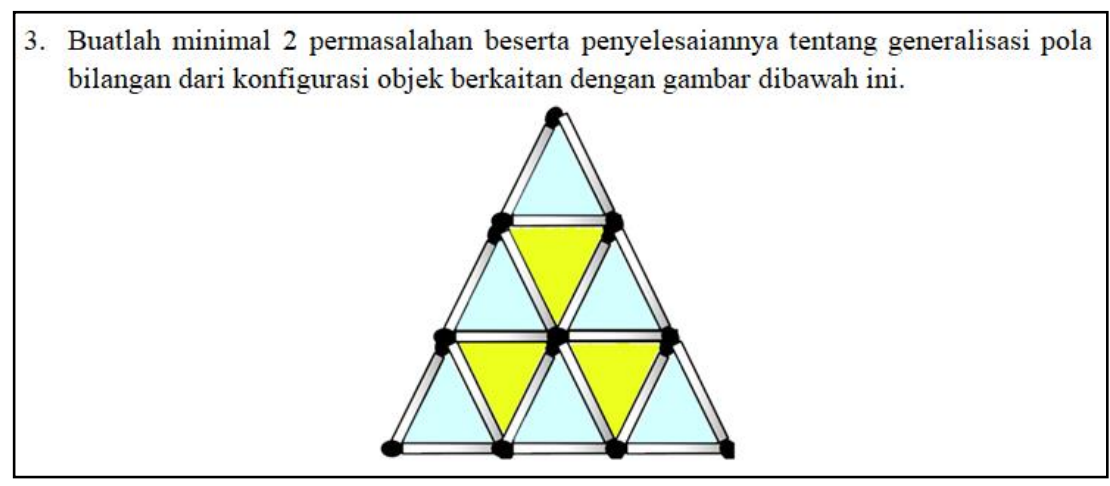

Gambar 8. Soal Tes Nomor 3

Pada soal nomor 3, masih banyak siswa yang belum membuat soal cerita, pada soal ini peneliti mengharapkan siswa untuk membuat soal cerita berdasarkan gambar yang diberikan.

a. Siswa Pertama (S1)

S1 merupakan salah satu siswa yang mengajukan lebih dari satu pertanyaan dengan soal cerita konteks susunan korek api. Pada saat pembelajaran, S1 terlihat aktif dalam membuat soal cerita. Berikut lembar jawaban S1 pada soal nomor 3. 


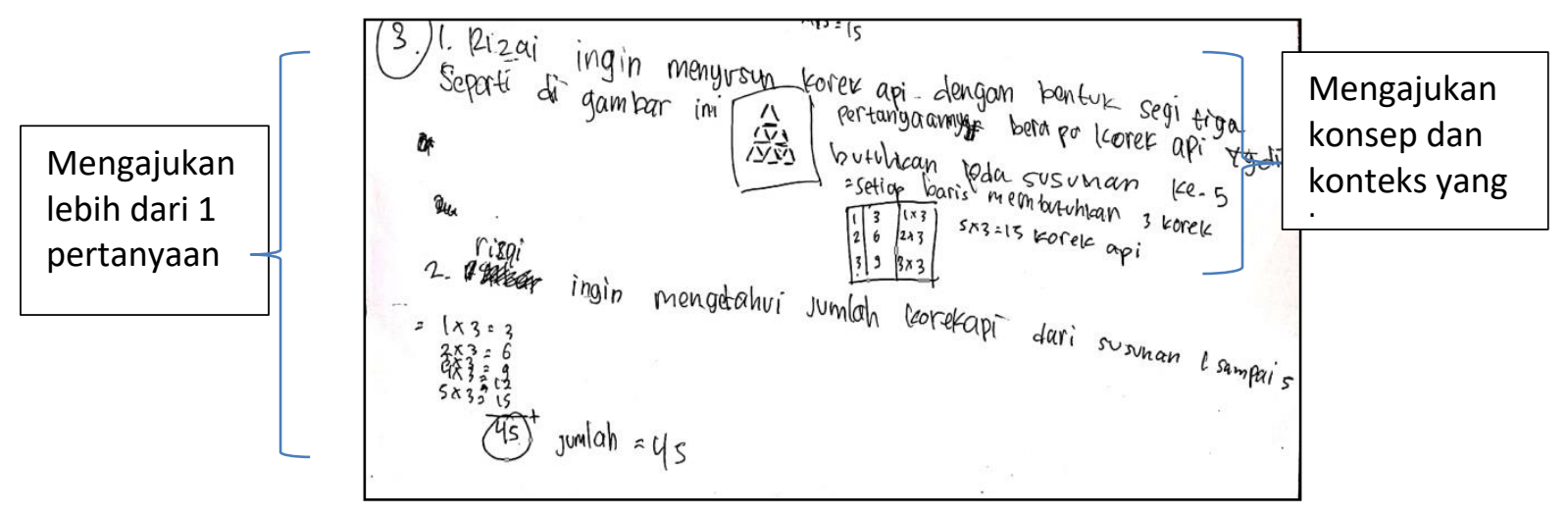

Gambar 9. Hasil Pengerjaan No. 3 oleh S1

Dari cuplikan gambar di atas, terlihat bahwa S1 membuat soal cerita tentang korek api dengan dirinya sendiri sebagai subjeknya. Ia kemudian mengajukan pertanyaan banyaknya korek api pada baris ke-5. S1 juga menjawabnya dengan menggunakan bentuk umum yang telah ia cari menggunakan tabel. Selain itu, pada soal yang kedua, S1 sedikit menemukan tentang konsep baru yaitu dengan menjumlahkan susunan-susunan korek api tersebut. Hal ini sudah mengarah pada konsep deret, meskipun S1 belum mengetahui apa bentuk umum dari deret tersebut, sehingga S1 juga telah memunculkan indikator kemampuan berpikir kreatif bidang fluency dan novelty dengan maksimal. Hal ini juga didukung dengan wawancara yang dilakukan peneliti dan siswa S1 sebagai berikut.

Peneliti : yang nomor 3 kan ada gambar segitiga, kenapa adek mau membuat soal tentang korek api?

Siswa : korek kan satuan, jadi mudah dihtung.

Peneliti : ohh.. terus oal nomor 3, adek terpikir utuk menjulahkan barisan 1-4. Kenapa adek bisa terpikir untuk menjumlahkannya?

Siswa : (masih belum mengerti pertanyaan peneliti)

Peneliti : (menjelaskan kembali maksud soal)

Siswa : karena soal sebelumnya ada gambar yang begini (arah tangan mengarah kesamping), jadi kepikiran soal yang kayak ini aja.

Oleh karena itu, peneliti memberikan skor 4 pada kedua indikator tersebut. Sehingga S1 memperoleh skor 8 untuk soal nomor 3.

\section{b. Siswa Ketiga (S3)}

S3 merupakan salah satu siswa yang mengajukan pertanyaan lebih dari 1 pertanyaan, namun pertanyaan yang dibuat S3 bukan merupakan soal kontekstual. Berikut lembar jawaban S3 pada soal nomor 3. 


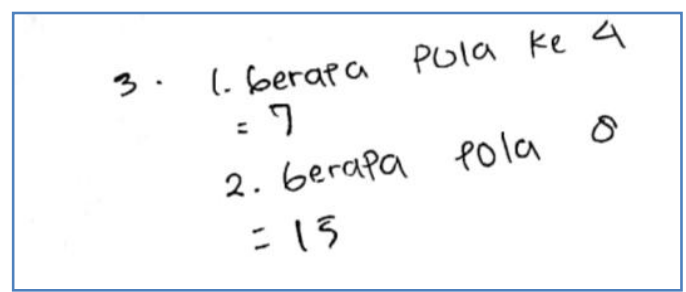

Gambar 10. Hasil Pengerjaan No. 3 oleh S3

Berdasarkan cuplikan di atas, S3 telah mengajukan lebih dari 1 pertanyaan tentang susunan pola pada gambar, sehingga peneliti memberikan skor 4 untuk indikator 3. Namun S3 tidak membuat soal kontekstual ataupun konsep baru, sehingga peneliti memberikan skor 0 kepada S3. Hal ini didukung dengan wawancara yang dilakukan peneliti dan siswa S3 sebagai berikut.

Peneliti : adek disini buat pola ke-4 sama pola ke-8. Itu maksudnya apa sih?

Siswa : pola itu kayak barisan...

Peneliti : barisan? Coba lihat gambar ini.

Siswa : kayak.. kan ini kan 1 (sambil menunjuk baris pertama pada gambar)

Peneliti : maksudnya baris 1, pola 1. Baris dua pola 2. Berarti pola yang ke-4 ini, baris ke 4?

Siswa : iya.

Peneliti : baris ke-4 ada tujuh, gimana carinya?

Siswa : ini gan angka ganjil. 1, 3, 5, 7..

Peneliti : jadi, baris ke-4 ada 7 ?

Siswa : (mengangguk)

Peneliti : kenapa dari soal yang dibuat, soalnya hanya menanyakan jumlah segitiga tiap baris, ga kepikiran untuk buat soal cerita?

Siswa : bingung bu, gimana buatnya.

Peneliti : kenapa bingung?

Siswa : nentuin polanya aja masih keliru, apalagi buat soal cerita. Sama kurang waktu buat soalnya b, belum kepikir idenya.

Berdasarkan wawancara yang dilakukan, siswa belum bisa mengajukan pertanyaan yang baru, meskipun telah lancar untuk mengajukan pertanyaan.

\section{Pembahasan}

Berdasarkan hasil penelitian didapatkan analis kemampuan berpikir kreatif siswa yang muncul setelah pembelajaran dengan menggunakan PMRI. Berikut ini dijelaskan lebih lanjut mengenai indikator berpikir kreatif yang muncul dalam penelitian ini.

1. Indikator Fluency

Indikator fluency merupakan indikator yang sering muncul dalam kemampuan berpikir kreatif. Hal ini sejalan dengan penelitian yang dilakukan oleh Firdaus, Widodo, dan Rochintaniawati (2018) dengan hasil penelitiannya yaitu indikator fluency merupakan 
indikator yang paling tinggi. Hal ini dikarenakan siswa sudah dapat mengajukan lebih dari 1 pertanyaan pada situasi yang diberikan. Pertanyaan yang diajukan siswa juga beragam, dimulai dari menentukan suku ke-n ataupun suku ke 6, 7 atau lainnya.

\section{Indikator Flexibility}

Pada indikator flexibility, aspek yang dilihat yaitu hasil dari jawaban siswa dalam membuat/menentukan hal baru berdasarkan situasi yang diberikan. Beberapa siswa dapat menentukan pola yang dimaksud dari soal tes. Hal ini berkaitan dengan keluwesan siswa dalam mengembangkan permasalahan yang ada.

\section{Indikator Novelty}

Pada indikator novelty, masih banyak siswa yang belum bisa mengajukan masalah yang berbeda dari konteks sebelumnya. Siswa juga belum bisa untuk mengajukan pertanyaan terkait konsep baru. Hal yang baru inilah yang merupakan ciri dari berpikir kreatif.

Pada saat pembelajaran, siswa terlihat mengerti tentang konteks yang diberikan. Hal ini sesuai dengan penelitian yang dilakukan Fauziah, Putri, Zulkardi, dan Somakim (2017), yaitu dengan menggunakan PMRI siswa dengan mudah mengerti materi dan mendapat hal baru dalam pembelajaran. Meskipun demikian, juga terdapat beberapa kendala yang dialami peneliti, yaitu terdapat siswa yang terlihat kurang aktif dalam diskusi kelompok, serta masih bergantung pada anggota kelompok lain dalam mengisi LKPD. Hal ini sejalan dengan penelitian yang dilakukan Ahmad (2018) yaitu sulitnya membiasakan siswa aktif belajar dengan metode diskusi. Sehingga hanya beberapa siswa yang aktif dalam diskusi tersebut. Dan akibatnya saat mengisi lembar tes, siswa kesulitan dalam mengerjakan soal secara individu dan berakibat pada kemampuan berpikir kreatif siswa. Seperti pada soal nomor 2, siswa masih belum mengerti maksud dari soal, serta siswa juga belum paham apa yang diinginkan soal tersebut. Selain itu pada soal nomor 3, siswa masih kurang dalam membuat masalah kontekstual ataupun konsep hal baru.

Selain itu dalam mengajukan masalah, siswa masih perlu waktu yang cukup banyak. Hal ini karena keterbatasan yang dilakukan oleh peneliti. Peneliti hanya melakukan proses belajar mengajar sebanyak 2 pertemuan, sehingga siswa belum terbiasa untuk belajar menggunakan PMRI dan mem-posing masalah. Hal ini sesuai dengan Kausar, Tiya, dan Rahim (2016) pada penelitiannya, yaitu cenderung menggunakan waktu yang banyak untuk bisa disesuaikan dengan rencana pembelajaran yang telah dibuat. Untuk itu diperlukan jam pelajaran yang cukup banyak dalam melakukan pembelajaran untuk mengajukan masalah. 


\section{Simpulan}

Berdasarkan hasil penelitian di kelas VIII.3 SMP Negeri 15 Palembang, diketahui bahwa kemampuan berpikir kreatif siswa kelas VIII.3 dikategorikan kreatif, dengan persentase 69,23\%. Hal ini dikarenakan, secara keseluruhan siswa sudah dapat mengajukan masalah dengan lancar dan fleksibel, meskipun belum mengarah pada suatu konsep ataupun konteks baru baru.

Namun pada penelitian ini, terdapat beberapa keterbatasan yaitu pertanyaan yang diajukan siswa masih sangat umum, peneliti mengharapkan soal baru yang lebih khusus, ataupun memuat konsep baru sehingga dapat meningkatkan pemahaman siswa. Hal ini dikarenakan siswa belum terbiasa menjawab dan membuat soal. Sehingga bagi peneliti lain diharapkan untuk menambahkan jumlah pertemuan dalam menerapkan problem posing pada pembelajaran.

\section{Ucapan Terimakasih}

Peneliti mengucapkan terima kasih kepada Hibah Kompetitif Unsri 2019 dan siswa yang telah menjadi subjek penelitian serta guru matematika serta SMP Negeri 15 Palembang atas dukungan terhadap penelitian yang dilakukan peneliti.

\section{Referensi}

Ahmad. (2018). Penerapan metode diskusi dalam meningkatkan hasil belajar murid pada pembelajaran figh. Jurnal $A l$ Hikmah, 15(1), 60-79. https://doi.org/10.25299/jaip.2018.vol15(1).1585.

Disnawati, H., \& Nahak, S. (2019). Pengembangan lembar kerja siswa berbasis etnomatika tenun Timor pada materi pola bilangan. Jurnal Elemen, 5(1), 64-79. https://doi.org/10.29408/jel.v5i1.1022.

Fauziah, A., Putri, R., Zulkardi, \& Somakim. (2017). Primary school student teachers' perception to Pendidikan Matematika Realistik Indonesia (PMRI) instruction. Journal of Physics: Conference Series, 1-8. https://doi.org/10.1088/1742-6596/943/1/012044.

Fauziah, Zulkardi, \& Putri, R. I. (2016). Desain pembelajaran materi belah ketupat menggunakan kain jumputan Palembang untuk siswa kelas VII. Jurnal Matematika Kreatif-Inovatif, 7(1), 31-40. https://doi.org/10.15294/kreano.v7i1.4829.

Firdaus, M., Widodo, \& Rochintaniawati. (2018). Analisis kemampuan berpikir kreatif dan proses pengembangan kemampuan berpikir kreatif siswa SMP pada pembelajaran biologi. Indonesian Journal of Biology Education, 21-28. https://doi.org/10.17509/aijbe.v1i1.11452.

Florida, Richard, Mellander, C., \& King. (2015). The global creativity index. Martin Prosperity Institute.

Idris, I., \& Silalahi, D. (2016). Penerapan pendekatan Pendidikan Matematika Realistik Indonesia (PMRI) untuk meningkatkan kemampuan penyelesaian soal cerita pada kelas VII A SMP UTY. Jurnal EduMatSains, 1(1), 73-82. 
Jayanto, I., \& Noer, S. H. (2017). Kemampuan berpikir kreatif dengan pembelajaran guided discovery. Prosiding Seminar Nasional Matematika dan Pendidikan Matematika.

Juliant, A., \& Kurnia. (2016). Analisis kesalahan siswa dalam menyelesaikan soal pada materi pola bilangan ditinjau dari kemampuan matematika siswa. Jurnal Riset Pendidikan, 2(2), 111-118.

Kausar, A., Tiya, K., \& Rahim, U. (2016). Penerapan pendekatan pembelajaran problem posing untuk meningkatkan hasil belajar matematika siswa kelas X SMAN 10 Kendari pada materi pangkat, akar dan logaritma. Jurnal Pendidikan Matematika, 4(1), 15-28. https://doi.org/10.19184/jukasi.v4i3.6149.

Kemdikbud. (2018). Buku pegangan pembelajaran berorientasi pada keterampilan berpikir tingkat tinggi. dirjen guru dan tenaga kependidikan kemendikbud. Jakarta: Kemdikbud.

Lestari, D., Testiana, G., \& Agustinia, R. (2018). Kemampuan berpikir kreatif siswa dengan Pendekatan Matematika Realistik Indonesia (PMRI). Jurnal Pendidikan Matematika Rafa, 4(1), 79-92. https://doi.org/10.19109/jpmrafa.v4i1.3766.

Mulinda, Zubainur, C., \& Hidayat, M. (2018). Level kemampuan berpikir kreatif siswa melalui realistic mathematics education di Kelas VII MTsN 1 Banda Aceh. Jurnal Ilmiah Mahasiswa Pendidikan Matematika, 103-111.

Safaria, S., \& Sangila, M. (2018). Kemampuan berpikir kreatif matematis siswa SMP Negeri 9 Kendari pada materi bangun datar. Jurnal Al-Ta'dib, 11(2), 73-90. https://doi.org/10.31764/jtam.v2i1.220.

Silver. (1997). Fostering creativity through instruction rich in matematical problem solving and problem posing. Pittsburgh, USA. https://doi.org/10.1007/s11858-997-0003-X.

Situmorang, F. G., \& Zulkardi. (2019). Kemampuan generalisasi pada materi persamaan garis lurus dalam pembelajaran PMRI di SMP Negeri 45 Palembang. Lentera Sriwijaya: Jurnal Ilmiah Pendidikan Matematika, 1(1), 64-76. https://doi.org/10.36706/jls.v1i1.9570.

Susanti, E., \& Setianingsih , R. (2019). Kesalahan siswa dalam menyelesaikan soal pola bilangan model TIMSS. Jurnal Ilmiah Pendidikan Matematika, 8(2), 302-310. https://doi.org/10.32939/ejrpm.v2i1.283.

Widyastuti, W, \& Putri, R. (2018). Kemampuan berpikir kreatif siswa pada pembelajaran operasi pecahan menggunakan pendekatan Open-Ended. Jurnal Pendidikan Matematika, 12(2), 13-22. https://doi.org/10.21831/pg.v13i1.21167.

Zulkardi. (2002). Developing a learning environment on realistic mathematics education for indonesian student teachers. Disertasi tidak dipublikasikan. Enschede: University of Twente. 